\title{
Effects of Italian Ryegrass (IRG) Supplementation on Animal Performance, Gut Microbial Compositions and Odor Emission from Manure in Growing Pigs
}

\author{
Sungkwon Park ${ }^{1}\left(\right.$, Sungback Cho $^{2}$ and Okhwa Hwang ${ }^{3, * \mathbb{C}}$ \\ 1 Department of Food Science and Biotechnology, Sejong University, 209 Neundong-ro, Gwangjin-gu, \\ Seoul 05006, Korea; sungkwonpark@sejong.ac.kr \\ 2 Institute of Livestock Odor Control, Jeonju-Si, Jeollabuk-Do 55365, Korea; csb5418@daum.net \\ 3 National Institute of Animal Science, Rural Development Administration, 1500 Kongjwipatjwi-ro, \\ Iseo-myeon, Wanju-Gun, Jeollabuk-Do 55365, Korea \\ * Correspondence: hoh1027@korea.kr; Tel.: +82-10-3429-3450
}

Received: 21 March 2020; Accepted: 30 April 2020; Published: 2 May 2020

\begin{abstract}
Fermentable carbohydrate (FC) is a promising material to reduce odor emission from pig manure. This study was conducted to investigate the impact of diets containing Italian ryegrass (IRG), as a FC, on animal performance, odorous chemical and bacterial composition of manure. Pigs were weighed and fed diets containing various levels of IRG powder $(0 \%, 0.5 \%, 1.0 \%$ and $1.5 \%)$ for 28 days. At the end of the trial, manure was collected to analyze the chemical composition, odorous compounds and bacterial community structure. As dietary IRG levels increased, concentrations of phenols and indoles were decreased by $12 \%$ and $37 \%$ compared with control, respectively, without changes in growth performance. IRG treatment increased the relative abundances of genera belong to the family Lachnospiraceae, Ruminococcaceae, Veillonellaceae, Peptostreptococcaceae and Lactobacillaceae, in order Clostridiales of phylum Firmicutes, but decreased the relative abundances of genus Sphaerochaeta in phylum Spirochaetes and genus AB243818_g of family Porphyromonadaceae in phylum Bacteroidetes when compared with control. Results from the current study demonstrate that IRG supplemented diets had a beneficial effect of reducing the odorous compounds in manure, possibly by altering the bacterial community structure towards predominantly carbohydrate utilizing microorganisms in the large intestine.
\end{abstract}

Keywords: bacterial compositions; Italian ryegrass; phenols and indoles; pig manure

\section{Introduction}

Swine manure accounts for the highest ratio (40.6\%) of total manure discharging from animal facility [1]. Odor emitting from swine manure accounts for $34.6 \%$ from that of total livestock facilities and contributed to civil complaints, affecting environment, animal health and production [2]. The Korea's national regulation of malodor emission from livestock facilities was enacted in 2005 [3]. Odor mitigation management systems have been produced in the context of bio-chemical agents and mechanical technologies [4]. Equipment systems such as ventilation, biofilters and wet scrubbers are difficult to adopt in open-type ventilation systems that account for $54 \%$ of total swine farms in Korea [5]. Therefore, modulation of diet formulation is a more desirable strategy for odor mitigation than that of equipment systems [4].

Control of odor generation and attenuation of nutrient excretion depends on the essential formulation and balance of nutrients in the animal diet. De Lange et al. [6] showed that feed ingredients and nutrient factors are closely associated with gut fermentation and odor formation. In particular, fermentable carbohydrate (FC)-containing dietary fiber has been known to relieve constipation, increase 
nutrient digestibility and improve gut health, resulting in reducing odor emission via incorporating excessive nitrogen into the microbial biomass nitrogen [7-9]. Italian ryegrass (IRG) can be cultivated abundantly in Korea and used as a feed ingredient which levels of acid detergent fiber, neutral detergent fiber, acid detergent lignin and soluble and insoluble dietary fiber and non-structural carbohydrates are similar to those of sugar beet pulp, thus can provide abundant FC [10]. However, there are limited data on dietary IRG fiber content and the effects of supplementation on odor generation and gut microbial compositions in pigs. We hypothesized that IRG—rich in dietary fiber and FC content-would effectively decrease odor emission by improving gut fermentation. Therefore, this study was conducted to evaluate the effects of IRG powder on growth performance, manure chemical materials, odorous composition and bacterial community in growing-finishing pigs.

\section{Materials and Methods}

\subsection{Animal and Manure Management}

All procedures were conducted in accordance with guidelines No. 16 set by the National Institute of Animal Science Animal Care and Use Committee in 2008. Twenty cross-bred growing-finishing barrows [(Landrace $\times$ Yorkshire $) \times$ Duroc] with an average initial body weight (BW) of $38.70 \mathrm{~kg}, 5$ for 4 treatments (IRG $0 \%, 0.5 \%, 1.0 \%$ and $1.5 \%$ ), were randomly allotted to each pen equipped with a stainless steel feeder, a nipple waterer and slatted plastic floor. Ambient temperature in the facility was automatically maintained at approximately $25^{\circ} \mathrm{C}$ by a ventilation control system. Pigs were fed a diet typical for this BW, which was formulated to be adequate in all nutrients (Table 1) [11].

Table 1. Composition of experimental diets, as-fed basis.

\begin{tabular}{|c|c|c|c|c|c|}
\hline \multirow{2}{*}{ Items } & \multicolumn{5}{|c|}{ IRG $^{1}$} \\
\hline & $0 \%$ & $0.5 \%$ & $1.0 \%$ & $1.5 \%$ & Raw $^{6}$ \\
\hline \multicolumn{6}{|c|}{ Ingredients (\%; as fed basis) } \\
\hline Corn, yellow & 72.34 & 69.74 & 66.91 & 64.26 & - \\
\hline IRG $^{1}$, powder & 0.00 & 0.50 & 1.00 & 1.50 & - \\
\hline Soybean oil & 0.67 & 1.30 & 1.97 & 2.62 & - \\
\hline Molasses & 0.07 & 1.29 & 2.69 & 4.00 & - \\
\hline Soy meal $\left(\mathrm{CP}^{1} 44 \%\right)$ & 24.07 & 24.34 & 24.64 & 24.85 & - \\
\hline Limestone & 0.53 & 0.48 & 0.42 & 0.37 & - \\
\hline $\mathrm{DCP}^{1}$ & 1.52 & 1.55 & 1.57 & 1.60 & - \\
\hline Mineral mixture ${ }^{2}$ & 0.20 & 0.20 & 0.20 & 0.20 & - \\
\hline Vitamin mixture ${ }^{3}$ & 0.20 & 0.20 & 0.20 & 0.20 & - \\
\hline Salt & 0.30 & 0.30 & 0.30 & 0.30 & - \\
\hline Endopower ${ }^{4}$ & 0.05 & 0.05 & 0.05 & 0.05 & - \\
\hline BioPlus 2B 5 & 0.05 & 0.05 & 0.05 & 0.05 & - \\
\hline Total & 100 & 100 & 100 & 100 & - \\
\hline \multicolumn{6}{|c|}{ Analyzed chemical compositions } \\
\hline Moisture (\%) & 12.77 & 12.87 & 13.10 & 13.69 & 10.78 \\
\hline Crude protein (\%) & 15.44 & 16.23 & 14.98 & 15.52 & 13.48 \\
\hline Crude fiber $(\%)$ & 1.99 & 1.75 & 2.08 & 2.19 & 23.62 \\
\hline Crude ash $(\%)$ & 4.21 & 4.15 & 3.88 & 3.82 & 11.50 \\
\hline $\mathrm{DE}^{1}(\mathrm{kcal} / \mathrm{kg})$ & 4438 & 4127 & 4110 & 4050 & 4103 \\
\hline $\mathrm{Ca}(\%)$ & 1.01 & 0.91 & 0.92 & 1.06 & 0.56 \\
\hline $\mathrm{P}(\%)$ & 0.66 & 0.64 & 0.63 & 0.71 & 0.32 \\
\hline Lysine (\%) & 0.70 & 0.75 & 0.78 & 0.71 & 0.61 \\
\hline Methionine (\%) & 0.22 & 0.22 & 0.24 & 0.21 & 0.17 \\
\hline Threonine (\%) & 0.69 & 0.58 & 0.58 & 0.56 & 0.63 \\
\hline Tyrosine (\%) & 0.54 & 0.61 & 0.57 & 0.57 & 0.46 \\
\hline
\end{tabular}

${ }^{1}$ Abbreviations: IRG—Italian ryegrass; $\mathrm{CP}$-crude protein; $\mathrm{DCP}$-dicalcium phosphate; $\mathrm{DE}$-digestible energy. 2 Provided the following amounts per kilogram of diet: selenium $0.15 \mathrm{mg}$; manganese $0.03 \mathrm{~g}$; zinc $0.1 \mathrm{~g}$; iron $0.1 \mathrm{~g}$; iodine $0.5 \mathrm{mg}$; magnesium 0.1 g. ${ }^{3}$ Provided the following amounts per kilogram of diet: vitamin A $5500 \mathrm{IU}$; vitamin $\mathrm{D}_{3} 550 \mathrm{IU}$; vitamin E $27 \mathrm{IU}$; menadione sodium bisulfate $2.5 \mathrm{mg}$; pantothenic acid $27 \mathrm{mg}$; niacin $33 \mathrm{mg}$; riboflavin $5.5 \mathrm{mg}$; vitamin $B_{12} 0.04 \mathrm{mg}$; thiamin $5 \mathrm{mg}$; pyridoxine $3 \mathrm{mg}$; biotin $0.24 \mathrm{mg}$; folic acid $1.5 \mathrm{mg}$; choline chloride $700 \mathrm{mg} .{ }^{4}$ Mixture including $\alpha$-galactosidase, galactomannanase, xylanase, $\beta$-glucanase, $\alpha$-amylase, etc. ${ }^{5}$ Mixture including bacillus subtilis and bacillus licheniformis. ${ }^{6}$ RAW: only IRG not included with anything. 
IRG was seeded in October and harvested at the heading stage in April of the next year. After naturally dry under the sun, IRG hay was ground into particles with less than $2 \mathrm{~mm}$ size. Dietary adaptation period was given to pigs for a 25 day in pen. Thereafter, they were transferred to individual metabolism crates $\left(1.6 \times 0.8 \mathrm{~m}^{2}\right)$ that allowed for collection of manure with another 3-day adaptation period. Pigs were weighed at the beginning and end of the experimental period to assess BW change and to ensure the gain weight. During the trial, pigs were fed twice daily (09:00 and 16:00) with feed being mixed with water at a 1:2.5 ratio based on BW. Feed intake was recorded daily for calculating feed efficiency. From each metabolism crates manure was collected at twice weekly, added in enclosed manure storage container and stored in the freezer $\left(-20^{\circ} \mathrm{C}\right)$ until analysis. A detailed scheme of the feeding trial is presented in Figure 1.

\subsection{Manure Analysis}

Manure $\mathrm{pH}$ was measured using a pH meter (Model 850C, Schott, Mainz, Germany). Biochemical oxygen demand (BOD), chemical oxygen demand (COD), suspended solids (SS) and ammonium nitrogen $\left(\mathrm{NH}_{4}-\mathrm{N}\right)$ of manure were tested according to Standards Methods ES 04305, ES 04315, ES 04303 and ES 04908 respectively [12]. BOD concentration was measured using a dissolved oxygen meter (Orion Star A, electrode \#086030MD, Thermo Fisher Scientific, MA, USA). The samples for COD measurement were prepared with $0.005 \mathrm{M}$ potassium permanganate solution (Crown Analytical Reagent, Tokyo, Japan) in flask and boiled at $97^{\circ} \mathrm{C}$ for $30 \mathrm{~min}$ in water bath. Concentrations were calculated by amount of titrated with $0.005 \mathrm{M}$ potassium permanganate solution. SS was analyzed that $20 \mathrm{~mL}$ of manure was poured into a pre-weighed crucible, dried at $105{ }^{\circ} \mathrm{C}$ for $2 \mathrm{~h}$ and cooled in a desiccator. Total nitrogen (TN) was analyzed using an UV-Visible spectrophotometer (Model Cary 300, Agilent, CA, USA). Manure $50 \mathrm{~mL}$ was added in beaker with $10 \mathrm{~mL}$ of sodium hydroxide-potassium persulfate solution (Sigma-Aldrich, MO, USA). After boiling for $30 \mathrm{~min}$ at $120^{\circ} \mathrm{C}, 25 \mathrm{~mL}$ of supernatant was mixed with $5 \mathrm{~mL}$ of hydrochloric acid solution (hydrochloric acid (Merck, Darmstadt, Germany):water = 1:16). $\mathrm{NH}_{4}-\mathrm{N}$ was analyzed by Kjeldahl method using steam distillation system (Vapodest 50s, Gerhardt, Konigswinter, Denmark). The Kjeldahl procedure for total nitrogen determination is widely used for animal feed, fertilizer quality, environmental samples and biologic analysis [13]. Nitrogen was quantified to three steps of digestion, distillation and titration. Organic nitrogen containing samples are digested with sulfuric acid to ammonium sulfate; the ammonium is then liberated by raising the $\mathrm{pH}$ and measured by titration [14]. Manure was boiled with the solution which mixed perchloric acid, sulfuric acid and distilled water. Concentrations were calculated using the values of titrated with solutions of $40 \%$ sodium hydroxide, $2 \%$ boric acid and $0.1 \mathrm{~N}$ hydrogen chloride. All chemical materials were used the products from Junsei company (Tokyo, Japan).

Odorous compounds, including volatile fatty acid (VFA; short chain fatty acid (SCFA; acetic acid, propionic acid, butyric acid and valeric acid) and branched-chain fatty acid (BCFA; iso-butyric acid and iso-valeric acid)), phenols (phenol and p-cresol) and indoles (indole and skatole), were measured by gas chromatography (GC; $6890 \mathrm{~N}$, Agilent, CA, USA) equipped with a flame ionization detector. VFA, phenols and indoles were analyzed by the previous methods reported by Hwang et al [15]. Briefly, $5 \mathrm{~mL}$ of manure was added to a $15 \mathrm{~mL}$ polypropylene centrifuge tube (Nunc, Thermo Fisher Scientific, MA, USA) along with $1 \mathrm{~mL}$ of $25 \%$ meta-phosphoric acid solution (Sigma-Aldrich, MO, USA) and $0.05 \mathrm{~mL}$ of saturated mercury (II) chloride solution (Sigma-Aldrich, MO, USA). Tubes were vortexed and centrifuged at $13,800 \times g$ for $10 \mathrm{~min}$ after at $3134 \times g$ for $20 \mathrm{~min}$ at $20^{\circ} \mathrm{C}$. The supernatant was filtered through a $0.2 \mu \mathrm{m}$ syringe filter (Merck, Darmstadt, Germany) and analyzed to VFA. Concentrations of phenols and indoles were analyzed that supernatant $(4 \mathrm{~mL})$ of centrifuged manure at $3134 \times g$ for $20 \mathrm{~min}$ at $20^{\circ} \mathrm{C}$ was mixed with $4 \mathrm{~mL}$ of chloroform (Merck, Darmstadt, Germany) and $60 \mu \mathrm{L}$ of $4 \mathrm{M}$ sodium hydroxide solution (Sigma-Aldrich, MO, USA). The supernatant was removed $2.0 \mathrm{~mL}$ GC vials (Agilent, CA, USA) after it was centrifuged at $3134 \times g$ for $20 \mathrm{~min}$ at $20^{\circ} \mathrm{C}$. Concentrations of VFA, phenols and indoles were determined by the external standard quantitation method with standard reagents of each compounds from Sigma-Aldrich (MO, USA). 


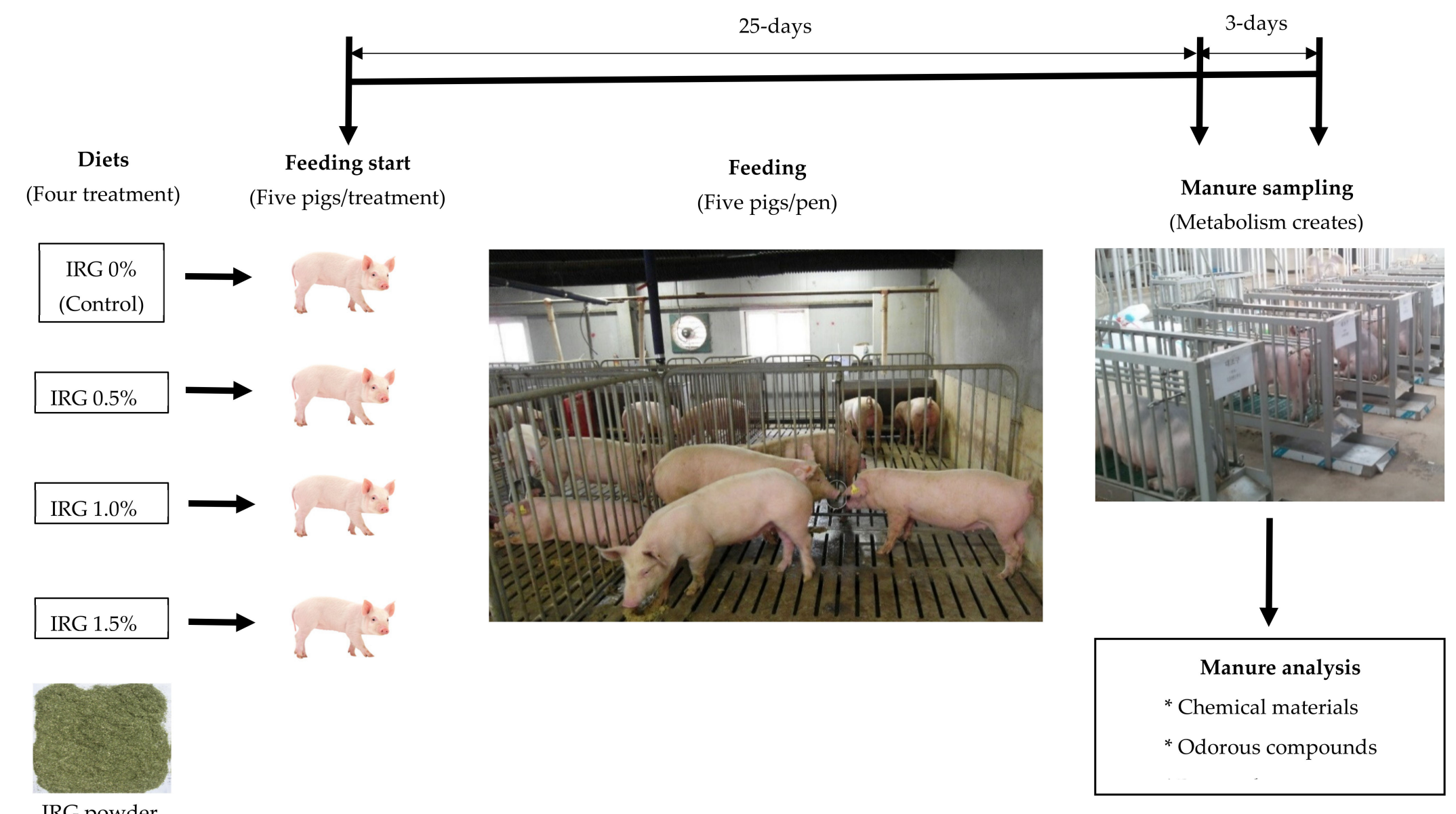

Figure 1. Schematic view of the experimental feeding trial. 


\subsection{Bacterial Community Analysis}

Total genomic DNA from manure was extracted using a Fast-DNA Spin Kit (MP Biomedicals, CA, USA) according to the manufacturer's instructions with modification [16]. Humic acid was removed using a Power-Clean DNA Clean-Up Kit (MP Biomedicals, CA, USA). Bacterial 16S ribosomal RNA genes (about 500-700 bp containing variable regions V1 to V3) were amplified using a bar-coded primer set [17]. Pyrosequencing was done by ChunLab (Seoul, Korea) using a 454 GS FLX Titanium Sequencing System (Roche, Basel, Switzerland). Taxonomic assignment of the bacterial high-quality reads was performed using the EzTaxon-e DB [18]. Sequences that cannot be matched to the EzTaxon-e $\mathrm{DB}$ at the species level (>97\%) are subjected to a secondary process checking for chimeric sequences using the UCHIME program [19]. Operational taxonomic units (OTUs) were generated by CD-HIT program at a $97 \%$ similarity level, the Shannon-Weaver diversity index, Chao1 richness index and Goods library coverage were calculated by the Mothur package [20]. Bacterial taxonomic compositions concerning levels of phylum and genus were classified at a cut off level of $>0.05 \%$ relative abundance.

\subsection{Statistical Analysis}

Statistical analyses on animal performance, chemical materials and odor compounds were performed with SAS Enterprise Guide 7.13 HF4 (SAS Institute, Inc., NC, USA) [21]. Data were analyzed as a completely randomized design with each treatment containing experimental units with individual pigs. The general linear model procedure and Duncan's multiple range test were used to test for significant differences at $p<0.05$. Treatment trends were discussed when $0.05>p<0.10$.

\section{Results \& Discussion}

\subsection{Animal Performance}

The effect of dietary IRG powder on animal performance is shown in Table 2. Dietary inclusion of IRG resulted in no significant differences $(p>0.05)$. The amount and the physicochemical composition of fiber source in the diet influence the energy, nutrient digestion and growth of animal. Although IRG diet contains about $8 \%$ less digestible energy (DE) than control diet ( $0 \%$ IRG diet), pigs in IRG group showed similar levels of average daily gain (ADG) and gain:feed (G:F) to those in control. In study of Gutierrez et al. [22], diet with corn bran including low DE did not affect the average daily feed intake (ADFI), ADG and G:F. The levels of dietary fiber and crude protein in corn bran are similar to those of IRG. Pig can tolerate quite a wide range of dietary fiber; if the dietary energy density is adequately provided, animals could maintain a growth performance [23]. Concomitant to these data, pigs fed IRG diet which contains $0.1 \%-0.2 \%$ more crude fiber than control diet did not show detrimental effect on their growth performance.

Table 2. Animal performance of pigs fed increasing levels of IRG.

\begin{tabular}{cccccccc}
\hline \multirow{2}{*}{ Items } & \multicolumn{9}{c}{ IRG } & \multirow{2}{*}{ SEM } & \multirow{2}{*}{ Linear } & \multirow{2}{*}{ Quadratic } \\
\cline { 2 - 5 } & $\mathbf{0 \%}$ & $\mathbf{0 . 5 \%}$ & $\mathbf{1 . 0} \%$ & $\mathbf{1 . 5 \%}$ & & & \\
\hline Initial body weight $(\mathrm{kg})$ & 37.40 & 38.96 & 37.60 & 40.85 & 1.18 & 0.46 & 0.74 \\
Final body weight $(\mathrm{kg})$ & 57.50 & 61.20 & 59.20 & 62.13 & 1.71 & 0.50 & 0.92 \\
Average daily gain $\left(\mathrm{kg} \mathrm{day}^{-1}\right)$ & 0.33 & 0.36 & 0.35 & 0.33 & 0.01 & 0.83 & 0.48 \\
Gain/feed & 0.19 & 0.20 & 0.19 & 0.18 & 0.01 & 0.69 & 0.48 \\
\hline
\end{tabular}

Abbreviations: IRG—Italian ryegrass; SEM—-standard error of the mean.

\subsection{Chemical Materials and Odor Compounds of Manure}

Manure characteristics including chemical materials and odor compounds are depicted in Tables 3 and 4 , respectively. Compare to control group, both $1.0 \%$ and $1.5 \%$ IRG treatments increased significantly $(p<0.05)$ COD ( $17 \%$ and $28 \%$, respectively) and SS ( $38 \%$ and $50 \%$, respectively). COD and SS are the parameters for determining the amount of typical organic substance and level of odor release from 
manure [24]. Pigs fed the diets with fiber had higher levels of organic indicator including solids, carbon and nitrogen in the manure [25]. Degradation of greater molecular weight components like fibers leads to an increase in the production of biodegradable soluble intermediates that can be metabolized by microbes [26].

Table 3. Chemical characterization of manure from pigs fed diets increasing levels of IRG.

\begin{tabular}{cccccccc}
\hline \multirow{2}{*}{$\begin{array}{c}\text { Items } \\
\left(\mathbf{m g ~ L}^{-1}\right)\end{array}$} & $\mathbf{0} \%$ & $\mathbf{0 . 5} \%$ & $\mathbf{1 . 0} \%$ & $\mathbf{1 . 5 \%}$ & SEM & Linear & Quadratic \\
\cline { 2 - 5 } & 9.07 & 9.16 & 9.13 & 8.84 & 0.06 & 0.16 & 0.13 \\
$\mathrm{pH}$ & 30,184 & 29,580 & 32,681 & 36,774 & 1318 & 0.05 & 0.39 \\
$\mathrm{BOD}$ & 13,845 & 14,607 & 16,717 & 19,099 & 642 & $<0.01$ & 0.45 \\
$\mathrm{COD}$ & 23,333 & 29,600 & 37,500 & 46,400 & 2881 & $<0.01$ & 0.79 \\
$\mathrm{SS}$ & 7908 & 8533 & 8457 & 8974 & 276 & 0.22 & 0.93 \\
$\mathrm{TN}$ & 2174 & 2882 & 2937 & 2552 & 98 & 0.08 & $<0.01$ \\
$\mathrm{NH}_{4}-\mathrm{N}$ & &
\end{tabular}

Abbreviations: IRG—Italian ryegrass; BOD—biologic oxygen demand; COD—chemical oxygen demand; SS—-suspended solids; $\mathrm{TN}$ — total nitrogen; $\mathrm{NH}_{4}-\mathrm{N}$ —ammonium nitrogen; $\mathrm{SEM}$-standard error of mean.

Table 4. Concentrations of volatile fatty acids and odorous compounds in manure from pigs fed diets with increasing levels of IRG.

\begin{tabular}{cccccccc}
\hline \multirow{2}{*}{$\begin{array}{c}\text { Items } \\
\left(\mathbf{m g ~ L}^{-1}\right)\end{array}$} & $\mathbf{0 \%}$ & $\mathbf{0 . 5 \%}$ & $\mathbf{1 . 0} \%$ & $\mathbf{1 . 5 \%}$ & SEM & Linear & Quadratic \\
\cline { 2 - 5 } & $\mathbf{0} \%$ & & & \\
\hline AA & 3604 & 2618 & 2745 & 3842 & 150.30 & 0.49 & $<0.01$ \\
PA & 488 & 415 & 487 & 673 & 25.86 & $<0.01$ & 0.01 \\
BA & 341 & 287 & 347 & 507 & 24.11 & 0.01 & 0.03 \\
VA & 86 & 75 & 83 & 138 & 7.85 & 0.01 & 0.04 \\
i-BA & 71 & 59 & 64 & 88 & 3.02 & 0.02 & $<0.01$ \\
i-VA & 189 & 143 & 154 & 207 & 7.95 & 0.33 & $<0.01$ \\
SCFA & 4520 & 3395 & 3662 & 5160 & 199.83 & 0.18 & $<0.01$ \\
BCFA & 260 & 203 & 219 & 295 & 10.77 & 0.18 & $<0.01$ \\
\hline Phenol & 10.21 & 6.24 & 6.42 & 8.54 & 0.46 & 0.18 & $<0.01$ \\
-Cresol & 143.32 & 156.00 & 132.32 & 95.43 & 4.56 & $<0.01$ & $<0.01$ \\
Indole & 6.83 & 4.29 & 3.27 & 4.45 & 0.44 & 0.02 & 0.03 \\
Skatole & 2.18 & 1.98 & 1.60 & 1.33 & 0.09 & $<0.01$ & 0.81 \\
Phenols & 153.53 & 162.24 & 138.74 & 103.97 & 4.48 & $<0.01$ & 0.01 \\
Indoles & 9.01 & 6.28 & 4.87 & 5.78 & 0.47 & $<0.01$ & 0.05 \\
\hline
\end{tabular}

Abbreviations: IRG—Italian ryegrass; AA—acetic acid; PA—propionic acid; BA—butyric acid; VA—valeric acid; i-BA-iso-butyric acid; i-VA - iso-valeric acid; SCFA—straight chain fatty acid (sum of acetic acid, propionic acid, butyric acid and valeric acid); BCFA—branched chain fatty acid (sum of iso-butyric acid and iso-valeric acid); Phenols—sum of phenol and $p$-cresol; Indoles—sum of indole and skatole; SEM—standard error of mean.

Concentrations of SCFA and BCFA from manure were quadratically treatment effects $(p<0.05)$ upon dietary IRG (Table 4). Administration of 1.5\% IRG increased the levels of both SCFA and BCFA by $12 \%$ relative to control, respectively. However, decreasing effect in VFA was found in $0.5 \%$ or $1.0 \%$ IRG group. Dietary fiber contains considerable amount of FC. Between 10 and $60 \mathrm{~g} \mathrm{day}^{-1}$ of dietary carbohydrate reaches in the large intestine [27]. The principal sources are resistant starch (RS; 8-40 $\left.\mathrm{g} \mathrm{day}^{-1}\right)$, non-starch polysaccharides (NSP; 8-18 $\left.\mathrm{g} \mathrm{day}^{-1}\right)$, unabsorbed sugars $\left(2-10 \mathrm{~g} \mathrm{day}^{-1}\right.$ ) and oligosaccharides (2-8 $\left.\mathrm{g} \mathrm{day}^{-1}\right)$ [28]. Carbohydrates are metabolized into SCFA $(40 \%)$, lactate $(15 \%)$, $\mathrm{CO}_{2}(5 \%)$ and bacterial biomass (40\%) [29]. SCFA level was remarkably increased by supplementation of inulin, a rich FC source, in pigs [30,31]. When pigs fed diets supplemented with 10\% soybean hull, SCFA increased by $32 \%$, but other odorants decreased by $10 \%-20 \%$ [32]. VFA concentrations depend on the type and level of FC included in diets [33]. SCFA can provide about $24 \%-30 \%$ of total energy needed for growing pigs [34]. The amount of carbohydrate consumed by animals has a profound influence on the rate of SCFA absorption by regulating the fermentation process in the large 
intestine [35-37]. Excessive consumption of FC, however, results in excretion of larger amount of SCFA that has not been converted to metabolic energy.

Dietary IRG supplementation effected the phenols and indoles levels in manure showing both linear $(p<0.05)$ and quadratic $(p<0.05)$ effects (Table 4$)$. Manure from $1.0 \%$ and $1.5 \%$ IRG groups had lower $10 \%$ and $32 \%$ phenols than those in control. Level of $p$-cresol, which is the main compound of phenols, was significantly lower in manure of finishing pigs fed diets with RS than in control [38]. Indoles were decreased by $46 \%$ and $36 \%$ in $1.0 \%$ and $1.5 \%$ IRG treatment, respectively. In particular, skatole concentration was linearly decreased ( $9 \%-39 \%)$ by increasing IRG levels $(0.5 \%-1.5 \%)$. Dietary fiber content is closely associated with protein excretion levels [39]. The lower degradability of fiber is in the hindgut, the greater excretion of amino acids is [22]. However, dietary FC decreased the excretion of indoles in pig manure on the low digestion rate of tryptophan in the large intestine [40-42]. Five percent chicory inulin supplementation decreased the skatole level in manure of growing pig [30]. The inclusion of FC supports the growth of beneficial bacteria in that highly activated bacterial population accelerates protein synthesis thus decreases proteolytic fermentation [43]. Consequently, odorous chemical production which is originated from protein excretion is reduced in manure. In addition, butyrate, which is known to decrease mucosal apoptosis, limits the availability of endogenous tryptophan $[44,45]$. We found significant decrease in skatole level with increased SCFA by $1.5 \%$ IRG treatment. The antimicrobial effect of acidic conditions by VFA suppresses the rate of skatole synthesis by inhibiting the growth of skatole-producing bacteria $[42,46,47]$.

Biochemical and physical factor of manure presented the linear correlation coefficients with odor production $[48,49]$. In this study, BOD and COD showed significantly $(p<0.05)$ positive related to SCFA (Figure 2a) and BCFA (Figure 2b), but COD had a negative correlation to phenols (Figure 2c). The chemical parameters of manure are used to detect the organic compounds in wastewater. BOD is an indicator of dissolved oxygen content that is consumed by bacteria [50]. The decreasing BOD levels have shown to inhibit the production of odorous compounds, resulting from decrease in the degradation rate of organic matter by bacteria [51]. Highly significant correlation coefficients were found in linear relationship between VFA and BOD produced during manure storage [52,53]. BOD exists a definite correlation with COD under wastewater treatment systems. In anaerobic treatment, COD is a factor to estimate the removal efficiencies of phenol compounds from wastewater [54,55]. Phenolic compounds could release from the degradation of lignocellulose that contains up to $40 \%-50 \%$ in total solids of pig manure. However, substantial amount of lignocellulose is difficult to biodegrade by bacteria [56]. COD is measured by chemical digestion of organic matter including lignocellulosic substances (cellulose, hemicellulose and lignin) with acidic reagents [50]. Therefore, phenols have the positively relation with COD, but in this study showed opposite pattern. In the study of Birkett et al. [57], total excretion of phenols decreased significantly from the high RS diets, whereas nitrogen output increased. Because bacteria require the nitrogen sources to growth and also acts as nitrogen sinks in manure, increased bacterial growth by FC is higher manure excretion of nitrogen as organic matter. In this study, concentration of TN increased by adding IRG, whereas phenols decreased (Table 3). Consequently, negatively correlation would be found between COD and phenols. 
(a)

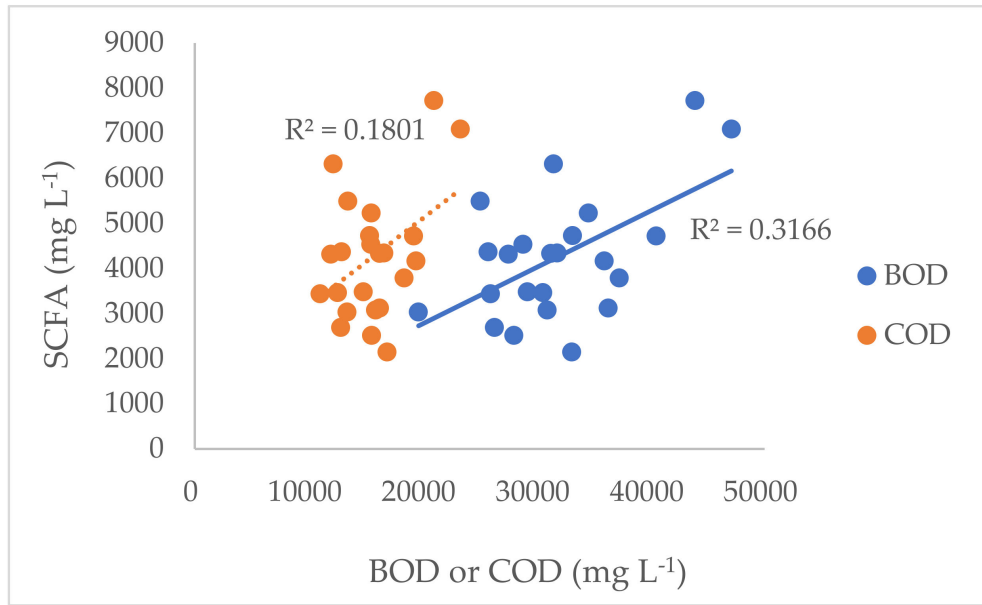

(b)

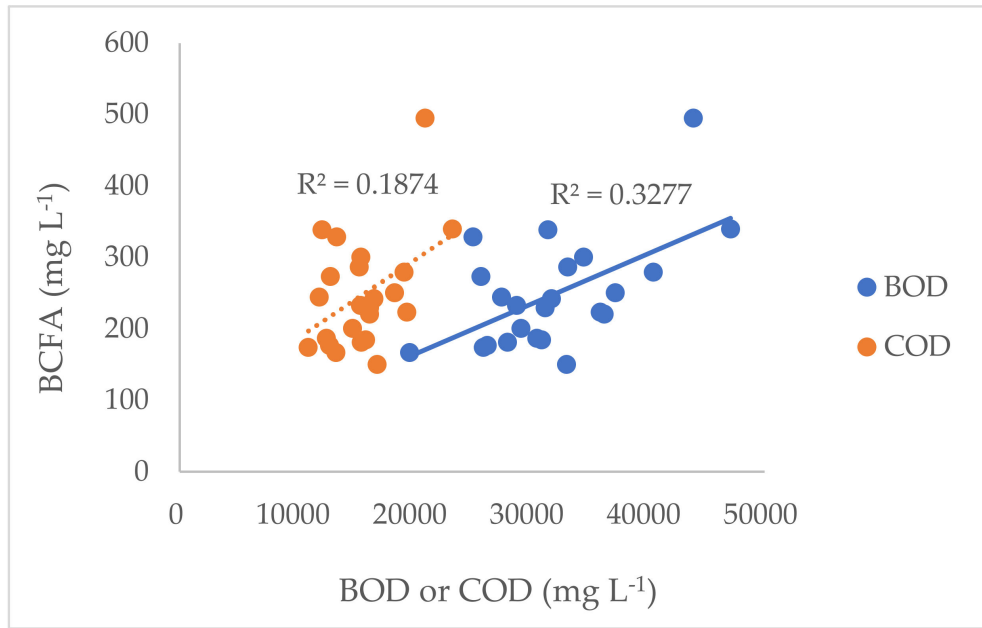

(c)

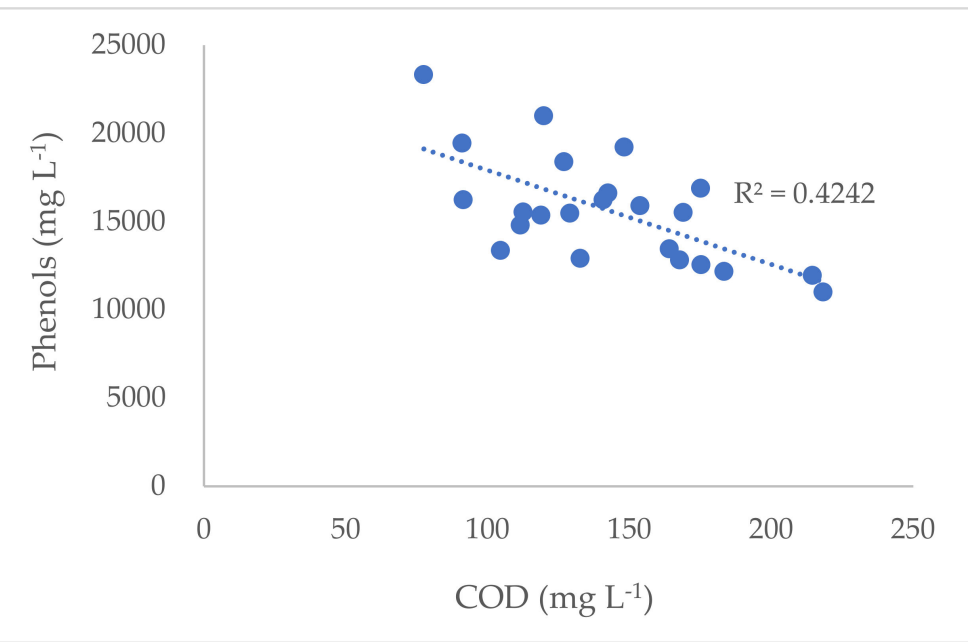

Abbreviations: SCFA — short chain fatty acid (sum of acetic acid, propionic acid, butyric acid and valeric acid); BCFA — branched chain fatty acid (sum of iso-butyric acid and iso-valeric acid); Phenols—sum of phenol and $p$-cresol; BOD—biochemical oxygen demand; COD—chemical oxygen demand; $p<0.05$.

Figure 2. Relationship between chemical materials and odorous compounds in pigs' manure. (a) BOD or COD with SCFA; (b) BOD or COD with BCFA; (c) COD with phenols. 


\subsection{Bacterial Community Composition}

Formation of odor compounds are influenced by changes in bacterial diversity and composition from diet formulation [58]. The IRG 1.0\% group was chosen for analysis of the changes in bacterial community based on overall odor reducing efficiency of manure in the current study. Concomitant to previous result, control (IRG 0\%) and IRG 1.0\% treatment group showed different correlation in the level of odorous compounds with the structure of bacterial community. Total reads of pyrosequencing were 9344 and 6552 in the control and IRG group, respectively (Table 5). After the removal of low-quality reads, 6589 (control) and 4041 (IRG) sequences were used for further analysis. Although the IRG group had a lower number of bacterial reads than control, the diversity indices as OTUs, Shannon-Weaver and Chao1 were not different between control and IRG group.

Table 5. Bacterial enumeration and diversity indices for manure of pigs fed a diet with control $(0 \%$ IRG) or IRG (1.0\%).

\begin{tabular}{ccc}
\hline \multirow{2}{*}{ Items } & \multicolumn{2}{c}{ Treatment } \\
\cline { 2 - 3 } & Control & IRG \\
\hline No. of total reads & 9344 & 6552 \\
No. of high-quality reads & 6589 & 4041 \\
Read length (bp) & 504 & 504 \\
OTUs & 1336 & 1100 \\
Shannon-Weaver index & 5.06 & 5.31 \\
Chao1 index & 2780 & 2230 \\
Goods library coverage & 0.92 & 0.90 \\
\hline
\end{tabular}

Abbreviations: IRG-Italian ryegrass; OTUs—operational taxonomic units.

Taxonomic profiles for bacterial communities from treatment groups are shown in Figures 3 and 4. Twenty-one phyla were represented among the OTUs with the vast majority classified to 8 major phyla: Firmicutes, Spirochaetes, Bacteroidetes, Actinobacteria, Proteobacteria, Tenericutes, Synergistetes and Lentisphaerae (Figure 3). The relative abundances of Firmicutes and Proteobacteria were higher by $33 \%$ and $4 \%$, respectively, in IRG group than control. Spirochaetes, Bacteroidetes, Actinobacteria and Tenericutes were lower by $22 \%, 9 \%, 2 \%$ and $4 \%$, respectively, in IRG group than control. Differences between treatment groups were identified on the genus level (Figure 4). Six hundred and three bacterial genera were represented and distributed to the following phyla: Firmicutes $(43 \%)$, Proteobacteria $(20 \%)$, Bacteroidetes $(11 \%)$, Actinobacteria $(10 \%)$, Tenericutes $(3 \%)$, Lentisphaerae $(3 \%)$, Synergistetes ( $2 \%$ ) and Spirochaetes (1\%). Bacteria of Gram-positive by $60 \%$ and Gram-negative by $40 \%$ were classified in these genera. Among the dominant genera, the relative abundances of genera belong to the families Lachnospiraceae (GU324369_g, Clostridium_g9, Lachnospiraceae_uc and DQ794184_g), Ruminococcaceae (Ruminococcaceae_uc, GU112189_g and Clostridium_g25), Veillonellaceae (Veillonellaceae_uc), Peptostreptococcaceae (Clostridium_g4 and Peptostreptococcus) and Lactobacillaceae (Lactobacillus) of phylum Firmicutes were higher in IRG group than control. 


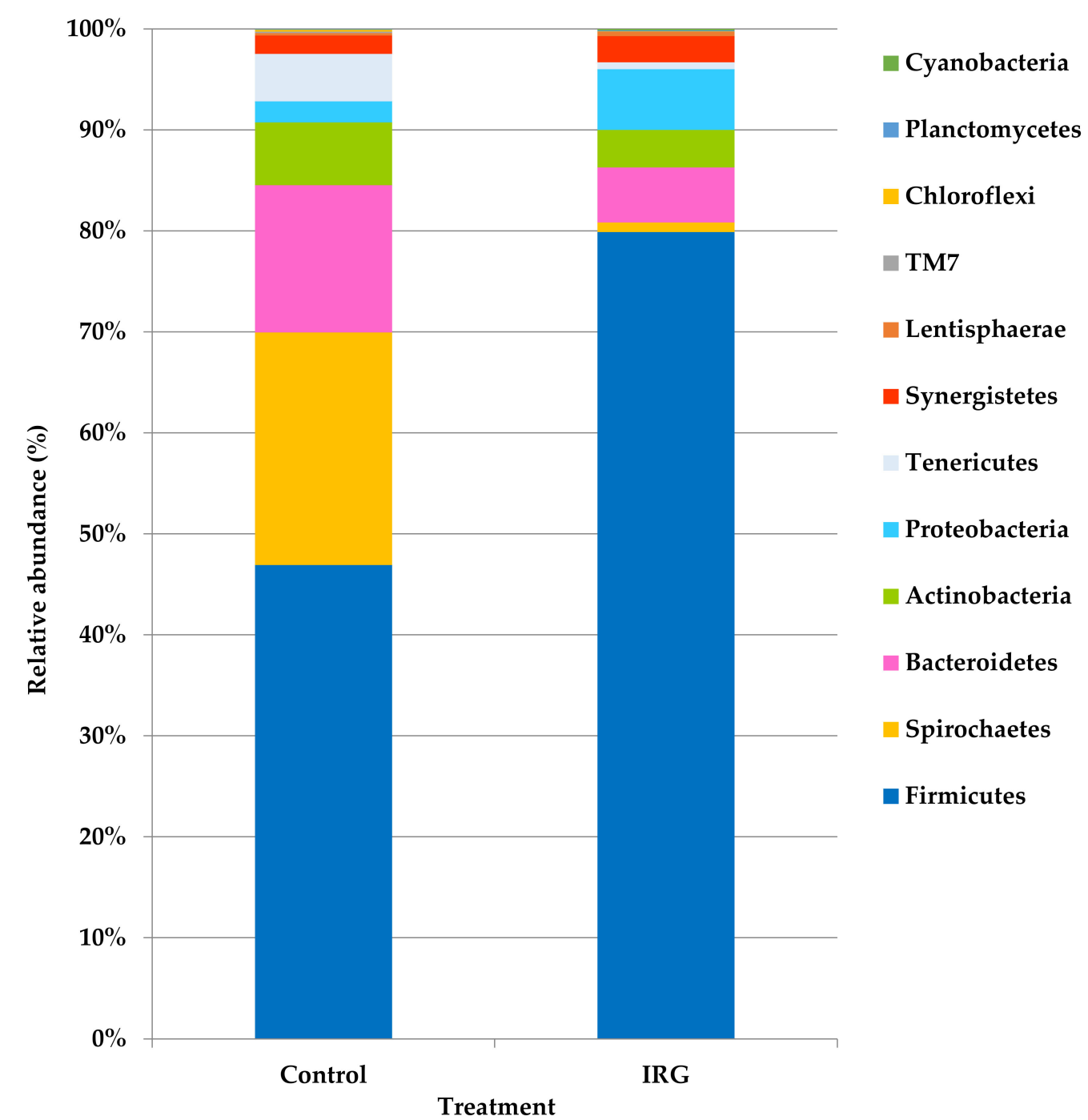

Abbreviations: IRG-Italian ryegrass; Bacterial phyla were classified at a cut off level of $>0.05 \%$ relative abundance.

Figure 3. Bacterial taxonomic compositions at phylum level for manure of pigs fed a diet with control $(0 \%$ IRG) or IRG $(1.0 \%)$. 


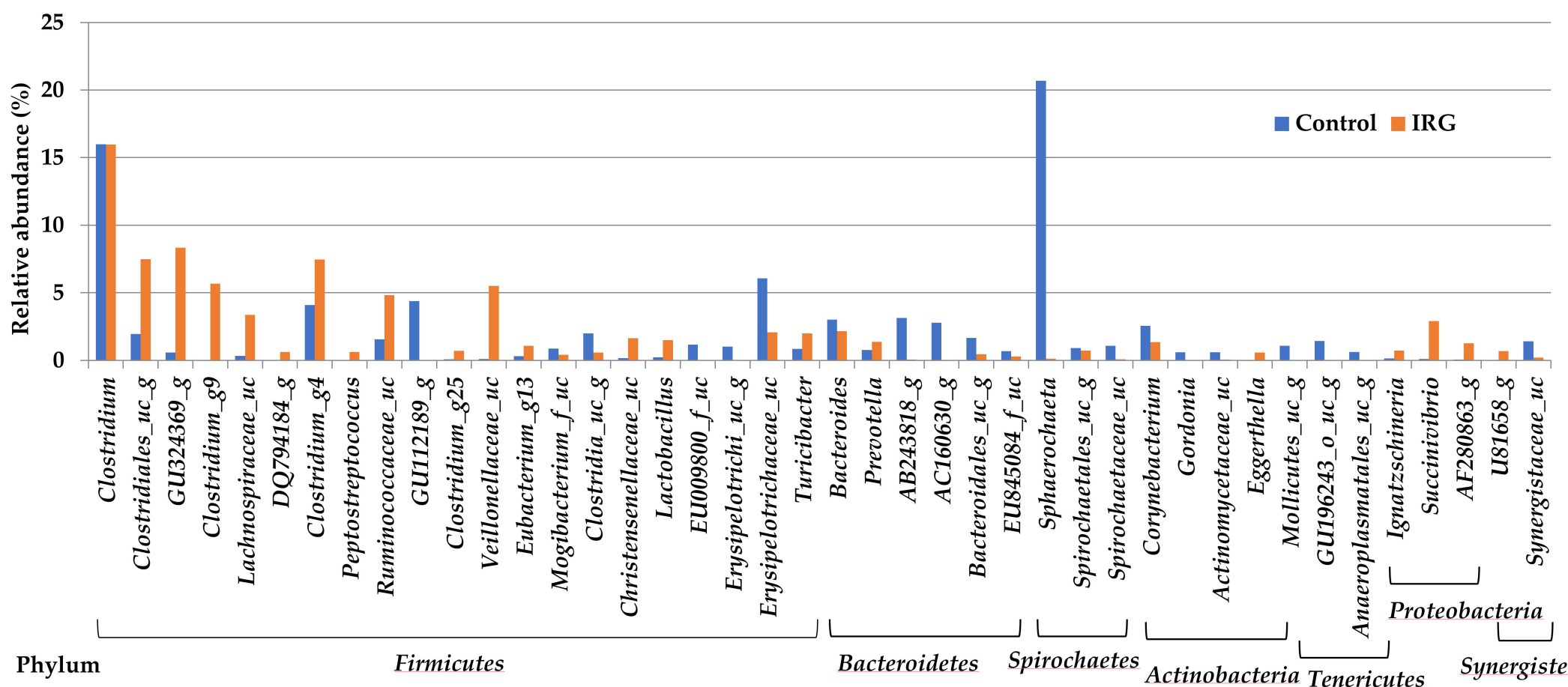

Abbreviations: IRG-Italian ryegrass; Bacterial genera were classified at a cut off level of $>0.05 \%$ relative abundance.

Figure 4. Bacterial taxonomic compositions at genus level for manure of pigs fed a diet with control ( $0 \%$ IRG) or IRG (1.0\%). 
Firmicutes account for $50 \%-80 \%$ in the community of core intestinal bacteria. Lachnospiraceae and Ruminococcaceae are the most abundant families in order Clostridiales of phylum Firmicutes, accounting for roughly $50 \%$ and $30 \%$ of Firmicutes, respectively [59,60]. These families obligated fibrolytic and saccharolytic microbes produce SCFA [61,62], in particular butyric acid [63], by the fermentation of dietary fibers. Veillonellaceae produces acetate and propionate from NSP supplemented diets $[64,65]$ and has a positive correlation with isobutyrate and isovalerate production in deer [66]. Peptostreptococcaceae and Lactobacillales were also associated with the increased VFA concentrations by FC supplementation. The abundance of Peptostreptococcus spp. was increased in feces of pigs fed a diet including $8.7 \%$ RS [67]. It has been shown that Lactobacillales has grown up a large amount in the colon of humans (Oligosaccharides) [68], rats (Sorghum bran) [69] and dogs (Mixture of fiber and resistant starch) [70] fed carbohydrate supplemented diets. In addition, the increase of Lactobacillus supports the observation of increased VFA levels in the colon and feces of humans (Apple) [71], pigs and rats (RS and arabinoxylan) [72] fed FC diets. However, our results suggest that an increase in relative abundances of the genera belonging to five families are not associated with the changes of VFA levels (Table 4 and Figure 4) implicating that other bacterial groups may be involved with the changes of VFA levels.

Genus Sphaerochaeta in phylum Spirochaetes was decreased in IRG (1\%) group compared with control (IRG 0\%). Spirochaetes are frequently detected in the wastewater of livestock production, industry and anaerobic digestion systems [73]. SCFA is mainly originated from carbohydrate fermentation [74] and also used by Sphaerochaeta under anaerobic conditions $[75,76]$. More than $10 \%$ of the core genes and presumably more than $50 \%$ of the auxiliary and secondary metabolism genes of Sphaerochaeta are acquired from members of Firmicutes, especially order Clostridiales. Several genes related to carbohydrate metabolism of Spirochetes spp. have been acquired from co-occurring members of Clostridiales in the large intestine of pig [77]. In addition, two bacterial members have a common ecological niche [10]. Biomass yields of cellulose degradation by Clostridiales increase by co-culture with Spirochaeta [78]. In our current study, an increase in the proportion of order Clostridiales (from $30 \%$ to $62 \%$ ) belonging to representative families of Lachnospiraceae, Ruminococcaceae, Veillonellaceae and Peptostreptococcaceae under the IRG supplemented condition may be associated with a decrease of Spirochaetes (from 22\% to 1\%).

In addition, order Clostridiales were also identified in many studies as aromatic hydrocarbon degraders $[79,80]$. Families belonging to this order were dominated in the waste with an anaerobic treatment and subsequent lower level of phenol [81]. Decrease in phenols in IRG treatment (IRG $1 \%$ ) may be associated with enrichment of these families. By contrast, genus $A B 243818 \_g$ of family Porphyromonadaceae decreased in IRG group compared with control. This bacterial strain, which is dominant family of the phylum Bacteroidetes, produces skatole during the process of decarboxylation and deamination of tryptophan [82]. The increased relative abundance of order Clostridiales as acid producing bacteria inhibits the growth of skatole producing bacteria $[42,46,47]$. These results suggest that mechanism by which IRG treatment decreases the skatole level possibly via modulating the bacterial proportion in the current study.

\section{Conclusions}

Our results demonstrate that IRG supplementation in pig diets significantly affected the composition of odorous compounds, as well as the bacterial community in manure. Levels of odorous compounds-including phenols and indoles-were lower in manure of pigs fed supplementary IRG diets. In particular, skatole concentration dramatically decreased with increasing levels of dietary IRG. This is associated with changes in composition of bacterial community by IRG supplementation (IRG $1 \%$ ) in that decrease the concentration of odorous compounds. IRG supplementation (IRG 1\%) in pig diets modulate relative abundances of the genera belong to the family Lachnospiraceae, Ruminococcaceae, Veillonellaceae, Peptostreptococcaceae and Lactobacillaceae in order Clostridiales of phylum Firmicutes, which predominantly utilize carbohydrate and produce acidic compounds as byproducts of fermentation. The high levels of this bacterial strains led to decrease of skatole levels by inhibit the population 
of skatole producing bacteria. Consequently, IRG supplementation (IRG 1\%) has a beneficial role for controlling the odorous compound formations via improving gut fermentation in pigs. Further investigation on the land-applied manure is needed in order to comprehensively assess the impact of FC on manure odor reduction.

Author Contributions: Conceptualization, O.H. and S.C.; methodology, O.H. and S.C.; validation, O.H., S.C. and S.P.; formal analysis, O.H. and S.C.; investigation, O.H. and S.C.; data curation, O.H. and S.P.; writing-original draft preparation, O.H. and S.P.; writing—review and editing, O.H. and S.P.; visualization, O.H. All authors have read and agreed to the published version of the manuscript.

Funding: This research was funded by National Institute of Animal Science (NIAS)—Rural Development Administration (RDA) Grant Number PJ90711003.

Acknowledgments: The authors would like to acknowledge the technical support provided by NIAS-RDA. This research was carried out with the support of "Cooperative Research Program for Agriculture Science and Technology Development (Project No. PJ90711003)" NIAS-RDA, Republic of Korea.

Conflicts of Interest: The authors declare no conflict of interest.

\section{Abbreviations}

ADFI—average daily feed intake; ADG—average daily gain; BCFA—branched chain fatty acid; BOD—biochemical oxygen demand; BW—body weight; COD—chemical oxygen demand; DE—digestible energy; FC—fermentable carbohydrate; GC—gas chromatography; G:F-gain:feed; IRG—Italian ryegrass; NH4-N_ammonium nitrogen; NSP — non-starch polysaccharides; OTUs—operational taxonomic units; RS — resistant starch; SCFA — short chain fatty acid; SS—-suspended solids; TN—total nitrogen; VFA—volatile fatty acid.

\section{References}

1. MAFRA (Ministry of Agriculture, Food and Rural Affairs). A Case Study of the Farm to Improving Livestock Odor; MAFRA (Ministry of Agriculture, Food and Rural Affairs): Sejong, Korea, 2018; Available online: http://lib.mafra.go.kr/Search/Detail/43789?key (accessed on 3 March 2020).

2. ACRC (Anti-Corruption and Civil Rights Commission). Census of Civil Complaints at 2017; ACRC (Anti-Corruption and Civil Rights Commission): Sejong, Korea, 2018.

3. ME (Ministry of Environment). Law on Offensive Odor Control; ME (Ministry of Environment): Sejong, Korea, 2012.

4. Maurer, D.L.; Koziel, J.A.; Harmon, J.D.; Hoff, S.J.; Rieck-Hinz, A.M.; Andersen, D.S. Summary of performance data for technologies to control gaseous, odor, and particulate emissions from livestock operations: Air management practices assessment tool (AMPAT). Data Brief 2016, 7, 1413-1429. [CrossRef]

5. Statistics Korea. Agriculture, Forestry and Fisheries 2015; Statistics Korea: Daejeon, Korea, 2015.

6. De Lange, C.; Pluske, J.; Gong, J.; Nyachoti, C. Strategic use of feed ingredients and feed additives to stimulate gut health and development in young pigs. Livest. Sci. 2010, 134, 124-134. [CrossRef]

7. Wenk, C. The role of dietary fibre in the digestive physiology of the pig. Anim. Feed Sci. Tech. 2001, 90, 21-33. [CrossRef]

8. De Leeuw, J.; Bolhuis, J.; Bosch, G.; Gerrits, W. Effects of dietary fibre on behaviour and satiety in pigs. Proc. Nutr. Soc. 2008, 67, 334-342. [CrossRef] [PubMed]

9. Oliviero, C.; Kokkonen, T.; Heinonen, M.; Sankari, S.; Peltoniemi, O. Feeding sows with high fibre diet around farrowing and early lactation: Impact on intestinal activity, energy balance related parameters and litter performance. Res. Vet. Sci. 2009, 86, 314-319. [CrossRef] [PubMed]

10. Calabro, S.; Moniello, G.; Piccolo, V.; Bovera, F.; Infascelli, F.; Tudisco, R.; Cutrignelli, M.I. Rumen fermentation and degradability in buffalo and cattle using the in vitro gas production technique. J. Anim. Physiol. Anim. Nutr. 2008, 92, 356-362. [CrossRef] [PubMed]

11. NRC (National Research Council). Nutrient Requirements of Swine; National Academy Press: Washington, DC, USA, 2012.

12. ME (Ministry of Environment). Standard methods for examination of water and wastewater; ME (Ministry of Environment): Sejong, Korea, 2017.

13. Saez-Plaza, P.; Navas, M.J.; Wybraniec, S.; Michalowski, T.; Asuero, A.G. An overview of the kjeldahl method of nitrogen determination. Part II. Sample preparation, working scale, instrumental finish, and quality control. Crit. Rev. Anal. Chem. 2013, 43, 224-272. [CrossRef] 
14. Saha, U.K.; Sonon, L.; Kissel, D.E. Comparison of conductimetric and colorimetric methods with distillation titration method of analyzing ammonium nitrogen in total kjeldahl digests. Commun. Soil Sci. Plant Anal. 2012, 43, 2323-2341. [CrossRef]

15. Hwang, O.H.; Cho, S.B.; Han, D.W.; Lee, S.R.; Kwag, J.H.; Park, S.K. Effect of storage period on the changes of odorous compound concentrations and bacterial ecology for identifying the cause of odor production from pig slurry. PLoS ONE 2016, 11, e0162714. [CrossRef]

16. Choi, Y.; Lee, S.; Lee, H.; Lee, S.; Kim, S.; Lee, J.; Ha, J.; Oh, H.; Lee, Y.; Kim, Y.; et al. Rapid Detection of Escherichia coli in Fresh Foods Using a Combination of Enrichment and PCR Analysis. Korean J. Food Sci. Anim. Resour. 2018, 38, 829-834.

17. Chun, J.; Kim, K.Y.; Lee, J.H.; Choi, Y. The analysis of oral microbial communities of wild-type and toll-like receptor 2-deficient mice using a 454 GS FLX Titanium pyrosequencer. BMC Microbiol. 2010, 10, 101. [CrossRef] [PubMed]

18. Kim, O.S.; Cho, Y.J.; Lee, K.; Yoon, S.H.; Kim, M.; Na, H.; Park, S.C.; Jeon, Y.S.; Lee, J.H.; Yi, H.; et al. Introducing EzTaxon-e: A prokaryotic 16S rRNA gene sequence database with phylotypes that represent uncultured species. Int. J. Syst. Evol. Micr. 2012, 62, 716-721. [CrossRef] [PubMed]

19. Edgar, R.C.; Haas, B.J.; Clemente, J.C.; Quince, C.; Knight, R. UCHIME improves sensitivity and speed of chimera detection. Bioinformatics 2011, 27, 2194-2200. [CrossRef] [PubMed]

20. Schloss, P.D.; Westcott, S.L.; Ryabin, T.; Hall, J.R.; Hartmann, M.; Hollister, E.B.; Lesniewski, R.A.; Oakley, B.B.; Parks, D.H.; Robinson, C.J.; et al. Introducing mothur: Open-source, platform-independent, community-supported software for describing and comparing microbial communities. Appl. Environ. Microbiol. 2009, 75, 7537-7541. [CrossRef]

21. SAS Institute Inc. SAS Enterprise Guide 7.13 HF4; SAS Institute Inc.: Cary, NC, USA, 2016.

22. Gutierrez, N.A.; Kerr, B.J.; Patience, J.F. Effect of insoluble-low fermentable fiber from corn-ethanol distillation origin on energy, fiber, and amino acid digestibility, hindgut degradability of fiber, and growth performance of pigs. J. Anim. Sci. 2013, 91, 5314-5325. [CrossRef]

23. Baird, D.M.; McCampbell, H.C.; Allison, J.R. Effects of levels of crude fiber, protein and bulk in diets for finishing hogs. J. Anim. Sci. 1975, 41, 1039-1047. [CrossRef]

24. Szogi, A.A.; Loughrin, J.H.; Vanotti, M.B. Improved water quality and reduction of odorous compounds in anaerobic lagoon columns receiving pre-treated pig wastewater. Environ. Technol. 2017, 39, 2613-2621. [CrossRef]

25. Trabue, S.; Kerr, B. Emissions of greenhouse gases, ammonia, and hydrogen sulfide from pigs fed standard diets and diets supplemented with dried distillers grains with solubles. J. Environ. Qual. 2013, 43, 1176-1186. [CrossRef]

26. Wu, J.J.; Park, S.H.; Hengemuehle, S.M.; Yokoyama, M.T.; Person, H.L.; Masten, S.J. The effect of storage and ozonation on the physical, chemical, and biological characteristics of swine manure slurries. Ozone-Sci. Eng. 1998, 20, 35-50. [CrossRef]

27. Cummings, J.; Macfarlane, G. The control and consequences of bacterial fermentation in the human colon. J. Appl. Bacteriol. 1991, 70, 443-459. [CrossRef]

28. Van Loo, J.; Coussement, P.; De Leenheer, L.; Hoebregs, H.; Smits, G. On the presence of inulin and oligofructose as natural ingredients in the western diet. Crit. Rev. Food Sci. Nutr. 1995, 35, 525-552. [CrossRef] [PubMed]

29. Delzenne, N.M.; Roberfroid, M. Physiological effects of non-digestible oligosaccharides. LWT-Food Sci. Technol. 1994, 27, 1-6. [CrossRef]

30. Rideout, T.C.; Fan, M.Z.; Cant, J.P.; Wagner-Riddle, C.; Stonehouse, P. Excretion of major odor-causing and acidifying compounds in response to dietary supplementation of chicory inulin in growing pigs. J. Anim. Sci. 2004, 82, 1678-1684. [CrossRef] [PubMed]

31. Wang, J.F.; Zhu, Y.H.; Li, D.F.; Wang, Z.; Jensen, B.B. In vitro fermentation of various fiber and starch sources by pig fecal inocula. J. Anim. Sci. 2004, 82, 2615-2622. [CrossRef]

32. De Camp, S.; Hill, B.; Hamkins, S.; Herr, C.; Richert, B.; Sutton, A.; Kelly, M.L.; Cobb, D.W.; Bundy, W.J. With added fat, soybean hulls may reduce odor without impairment. Feedstuff 2001, 10, 10-22.

33. Iyayi, E.; Adeola, O. Quantification of short-chain fatty acids and energy production from hindgut fermentation in cannulated pigs fed graded levels of wheat bran. J. Anim. Sci. 2015, 93, 4781-4787. [CrossRef]

34. Yen, J.; Nienaber, J.; Hill, D.; Pond, W. Potential contribution of absorbed volatile fatty acids to whole-animal energy requirement in conscious swine. J. Anim. Sci. 1991, 69, 2001-2012. [CrossRef] 
35. Bergman, E. Energy contributions of volatile fatty acids from the gastrointestinal tract in various species. Physiol. Rev. 1990, 70, 567-590. [CrossRef]

36. Jensen, B.B.; Jørgensen, H. Effect of dietary fiber on microbial activity and microbial gas production in various regions of the gastrointestinal tract of pigs. Appl. Environ. Microbiol. 1994, 60, 1897-1904. [CrossRef]

37. Knudsen, K.B. Nutritional and functional properties of fiber in swine diets. In Proceedings of the Midwest Swine Nutrition Conference, Indianapolis, IN, USA, 4 September 2014; p. 35.

38. Willig, S.; Lösel, D.; Claus, R. Effects of resistant potato starch on odor emission from feces in swine production units. J. Agric. Food Chem. 2005, 53, 1173-1178. [CrossRef]

39. Moughan, P.J. Amino acid digestibility and availability in food and feedstuffs. In Digestive Physiology in Pigs. Proc. 9th International Symposium; Ball, R.O., Ed.; University of Alberta: Edmonton, AB, Canada, 2003; Volume 1, pp. 199-221.

40. Hawe, S.M.; Walker, N.; Moss, B.W. The effects of dietary fiber, lactose and antibiotic on the levels of skatole and indole in feces and subcutaneous fat in growing pigs. Anim. Sci. 1992, 54, 413-419. [CrossRef]

41. Jensen, M.T.; Cox, R.P.; Jensen, B.B. 3-Methylindole (skatole) and indole production by mixed populations of pig fecal bacteria. Appl. Environ. Microbiol. 1995, 61, 3180-3184. [CrossRef] [PubMed]

42. Overland, M.; Kjos, N.P.; Borg, M.; Skjerve, E.; Sorum, H. Organic acids in diets for entire male pigs: Effect on skatole level, microbiota in digesta, and growth performance. Livest. Sci. 2008, 115, 169-178. [CrossRef]

43. Jha, R.; Berrocoso, J.F.D. Dietary fiber and protein fermentation in the intestine of swine and their interactive effects on gut health and on the environment: A review. Anim. Feed Sci. Tech. 2016, 212, 18-26. [CrossRef]

44. Hass, R.; Busche, R.; Luciano, L.; Reale, E.; Engelhardt, W. Lack of butyrate is associated with induction of Bax and subsequent apoptosis in the proximal colon of guinea pig. Gastroenterology 1997, 112, 875-881. [CrossRef]

45. Mentschel, J.; Claus, R. Increased butyrate formation in the pig colon by feeding raw potato starch leads to a reduction of colonocyte apoptosis and a shift to the stem cell compartment. Metabolism 2003, 52, 1400-1405. [CrossRef]

46. Claus, R.; Lösel, D.; Lacorn, M.; Mentschel, J.; Schenkel, H. Effects of butyrate on apoptosis in the pig colon and its consequences for skatole formation and tissue accumulation. J. Anim. Sci. 2003, 81, 239-248. [CrossRef]

47. Zamaratskaia, G.; Babol, J.; Andersson, H.; Andersson, K.; Lundström, K. Effect of live weight and dietary supplement of raw potato starch on the levels of skatole, androstenone, testosterone and oestrone sulphate in entire male pigs. Livest. Prod. Sci. 2005, 93, 235-243. [CrossRef]

48. Westerman, P.W.; Zhang, R.H. Aeration of livestock manure slurry and lagoon liquid for odor control: A review. Appl. Eng. Agric. 1997, 13, 245-249. [CrossRef]

49. Williams, A.G. Indicators of piggery slurry odour offensiveness. Agric. Wastes 1984, 10, 15-36. [CrossRef]

50. Abdalla, K.Z.; Hammam, G. Correlation between biochemical oxygen demand and chemical oxygen demand for various wastewater treatment plants in Egypt to obtain the biodegradability indices. Int. J. Sci. Basic Appl. 2014, 13, 42-48.

51. Zhu, J.; Ndegwa, P.M.; Luo, A. Effect of solid-liquid separation on BOD and VFA in swine manure. Environ. Technol. 2001, 22, 1237-1243. [CrossRef] [PubMed]

52. Ndegwa, P.M.; Zhu, J.; Luo, A. Effects of bioreactor temperature and time on odor-related parameters in aerated swine manure slurries. Environ. Technol. 2003, 24, 1007-1016. [CrossRef] [PubMed]

53. Zhang, Z.; Zhu, J. Characteristics of solids, BOD and VFAs in liquid swine manure treated by short-term low-intensity aeration for long-term storage. Bioresour. Technol. 2006, 97, 140-149. [CrossRef] [PubMed]

54. Orupold, K.; Masirin, A.; Tenno, T. Estimation of biodegradation parameters of phenolic compounds on activated sludge by respirometry. Chemosphere 2001, 44, 1273-1280. [CrossRef]

55. Razo-Flores, E.; Iniestra-Gonzalez, M.; Field, J.A.; Olguin-Lora, P.; Puig-Grajales, L. Biodegradation of mixtures of phenolic compounds in an upward-flow anaerobic sludge blanket reactor. Environ. Eng. 2003, 129, 999-1006. [CrossRef]

56. Tassew, F.A.; Bergland, W.H.; Dinamarca, C.; Bakke, R. Effect of particulate disintegration on biomethane potential of particle rich substrates in batch anaerobic reactor. Appl. Sci. 2019, 9, 2880. [CrossRef]

57. Birkett, A.; Muir, J.; Phillips, J.; Jones, G.; O’Dea, K. Resistant starch lowers fecal concentrations of ammonia and phenols in humans. Am. J. Clin. Nutr. 1996, 63, 766-772. [CrossRef] 
58. Mosenthin, R.; Hambrecht, E.; Sauer, W.; Garnsworthy, P.; Wiseman, J. Utilisation of Different Fibres in Piglet Feeds; Nottingham University Press: Nottingham, UK, 2001.

59. Biddle, A.; Stewart, L.; Blanchard, J.; Leschine, S. Untangling the genetic basis of fibrolytic specialization by Lachnospiraceae and Ruminococcaceae in diverse gut communities. Diversity 2013, 5, 627-640. [CrossRef]

60. Tap, J.; Mondot, S.; Levenez, F.; Pelletier, E.; Caron, C.; Furet, J.P.; Ugarte, E.; Munoz-Tamayo, R.; Paslier, D.L.E.; Nalin, R.; et al. Towards the human intestinal microbiota phylogenetic core. Environ. Microbiol. 2009, 11, 2574-2584. [CrossRef]

61. Daly, K.; Proudman, C.J.; Duncan, S.H.; Flint, H.J.; Dyer, J.; Shirazi-Beechey, S.P. Alterations in microbiota and fermentation products in equine large intestine in response to dietary variation and intestinal disease. Br. J. Nutr. 2012, 107, 989-995. [CrossRef]

62. Duncan, S.H.; Barcenilla, A.; Stewart, C.S.; Pryde, S.E.; Flint, H.J. Acetate utilization and butyryl coenzyme A (CoA): Acetate-CoA transferase in butyrate-producing bacteria from the human large intestine. Appl. Environ. Microbiol. 2002, 68, 5186-5190. [CrossRef] [PubMed]

63. Yang, J.; Martínez, I.; Walter, J.; Keshavarzian, A.; Rose, D.J. In vitro characterization of the impact of selected dietary fibers on fecal microbiota composition and short chain fatty acid production. Anaerobe 2013, 23, 74-81. [CrossRef] [PubMed]

64. Belenguer, A.; Duncan, S.H.; Holtrop, G.; Anderson, S.E.; Lobley, G.E.; Flint, H.J. Impact of pH on lactate formation and utilization by human fecal microbial communities. Appl. Environ. Microbiol. 2007, 73, 6526-6533. [CrossRef] [PubMed]

65. Bourriaud, C.; Robins, R.; Martin, L.; Kozlowski, F.; Tenailleau, E.; Cherbut, C.; Michel, C. Lactate is mainly fermented to butyrate by human intestinal microfloras but inter-individual variation is evident. J. Appl. Microbiol. 2005, 99, 201-212. [CrossRef] [PubMed]

66. Li, Z.; Wright, A.D.; Liu, H.; Fan, Z.; Yang, F.; Zhang, Z.; Li, G. Response of the rumen microbiota of sika deer (Cervus nippon) fed different concentrations of tannin rich plants. PLoS ONE 2015, 10, e0123481. [CrossRef]

67. Durmic, Z.; Pethick, D.W.; Mullan, B.P.; Accioly, J.M.; Schulze, H.; Hampson, D.J. Evaluation of large-intestinal parameters associated with dietary treatments designed to reduce the occurrence of swine dysentery. $\mathrm{Br}$. J. Nutr. 2002, 88, 159-169. [CrossRef]

68. Macfarlane, G.; Steed, H.; Macfarlane, S. Bacterial metabolism and health-related effects of galacto-oligosaccharides and other prebiotics. J. Appl. Microbiol. 2008, 104, 305-344. [CrossRef]

69. Ritchie, L.E.; Sturino, J.M.; Carroll, R.J.; Rooney, L.W.; Azcarate-Peril, M.A.; Turner, N.D. Polyphenol-rich sorghum brans alter colon microbiota and impact species diversity and species richness after multiple bouts of dextran sodium sulfate-induced colitis. FEMS Microbiol. Ecol. 2015, 91, fiv008. [CrossRef]

70. Wakshlag, J.J.; Simpson, K.W.; Struble, A.M.; Dowd, S.E. Negative fecal characteristics are associated with $\mathrm{pH}$ and fecal flora alterations during dietary change in dog. Int. J. Appl. Res. Vet. Med. 2011, 9, 278-283.

71. Shinohara, K.; Ohashi, Y.; Kawasumi, K.; Terada, A.; Fujisawa, T. Effect of apple intake on fecal microbiota and metabolites in humans. Anaerobe 2010, 16, 510-515. [CrossRef] [PubMed]

72. Nielsen, T.S.; Lærke, H.N.; Theil, P.K.; Sørensen, J.F.; Saarinen, M.; Forssten, S.; Knudsen, K.E.B. Diets high in resistant starch and arabinoxylan modulate digestion processes and SCFA pool size in the large intestine and faecal microbial composition in pigs. Brit. J. Nutr. 2014, 112, 1837-1849. [CrossRef] [PubMed]

73. Ben-Dov, E.; Shapiro, O.H.; Gruber, R.; Brenner, A.; Kushmaro, A. Changes in microbial diversity in industrial wastewater evaporation ponds following artificial salination. FEMS Microbiol. Ecol. 2008, 66, 437-446. [CrossRef] [PubMed]

74. Ritalahti, K.M.; Justicia-Leon, S.D.; Cusick, K.D.; Ramos-Hernandez, N.; Rubin, M.; Dornbush, J.; Loffler, F.E. Sphaerochaeta globosa gen. nov., sp. nov. and Sphaerochaeta pleomorpha sp. nov., free-living, spherical spirochaetes. Int. J. Syst. Evol. Microbiol. 2012, 62, 210-216. [CrossRef] [PubMed]

75. Lee, S.H.; Park, J.H.; Kang, H.J.; Lee, Y.H.; Lee, T.J.; Park, H.D. Distribution and abundance of Spirochaetes in full-scale anaerobic digesters. Bioresour. Technol. 2013, 145, 25-32. [CrossRef] [PubMed]

76. Shivani, Y.; Subhash, Y.; Tushar, L.; Sasikala, C.; Ramana, C.V. Spirochaeta lutea sp. nov., isolated from marine habitats and emended description of the genus Spirochaeta. Syst. Appl. Microbiol. 2015, 38, 110-114. [CrossRef] [PubMed] 
77. Bellgard, M.I.; Wanchanthuek, P.; La, T.; Ryan, K.; Moolhuijzen, P.; Albertyn, Z.; Babak, S.; Motro, Y.; Dunn, D.S.; Schibeci, D.; et al. Genome sequence of the pathogenic intestinal spirochete Brachyspira hyodysenteriae reveals adaptations to its lifestyle in the porcine large intestine. PLOS ONE 2009, 4, e4641. [CrossRef]

78. Pohlschroeder, M.; Leschine, S.B.; Canale-Parola, E. Spirochaeta caldaria sp. nov., a thermophilic bacterium that enhances cellulose degradation by Clostridium thermocellum. Arch. Microbiol. 1994, 161, 17-24. [CrossRef]

79. Madigou, C.; Poirier, S.; Bureau, C.; Chapleur, O. Acclimation strategy to increase phenol tolerance of an anaerobic microbiota. Bioresour. Technol. 2016, 216, 77-86. [CrossRef]

80. Wang, W.; Wang, S.; Ren, X.; Hu, Z.; Yuan, S. Rapid establishment of phenol and quinolone-degrading consortia driven by the scoured cake layer in an anaerobic baffled ceramic membrane bioreactor. Environ. Sci. Pollut. Res. 2017, 24, 26125-26135. [CrossRef]

81. Poirier, A.; Bize, A.; Bureau, C.; Bouchez, T.; Chapleur, O. Community shifts within anaerobic digestion microbiota facing phenol inhibition: Towards early warning microbial indicators? Water Res. 2016, 100, 296-305. [CrossRef] [PubMed]

82. Chung, K.T.; Anderson, G.M.; Fulk, G.E. Formation of indoleacetic acid by intestinal anaerobes. J. Bacteriol. 1975, 124, 573-575. [CrossRef] [PubMed]

(C) 2020 by the authors. Licensee MDPI, Basel, Switzerland. This article is an open access article distributed under the terms and conditions of the Creative Commons Attribution (CC BY) license (http://creativecommons.org/licenses/by/4.0/). 